American Journal of Applied Sciences 8 (12): 1378-1383, 2011

ISSN 1546-9239

(C) 2011 Science Publications

\title{
The Impact of Crisis and Macroeconomic Variables towards Islamic Banking Deposits
}

\author{
${ }^{1}$ Muhamad Abduh, ${ }^{1}$ Mohd Azmi Omar and ${ }^{2}$ Jarita Duasa \\ ${ }^{1}$ Department of Business Administration \\ ${ }^{2}$ Department of Economics, \\ Kulliyah of Economics and Management Sciences, \\ International Islamic University, Malaysia
}

\begin{abstract}
Problem statement: The nature of Islamic banks is different from conventional banks which may lead to a different deposit behavior of their depositors. This study aims to analyze the dynamic effects of interest and profit rate changes, production level, inflation and financial crisis towards the fluctuation of total deposits in Malaysian Islamic banks. Approach: Using monthly data from January 2000 to December 2010, cointegration test and vector error correction model were utilized to uncover the dynamic relationship between macroeconomic variables and crisis with total deposit of Islamic banking. Results: The results show that changes in interest and profit rate as well as production growth has no significant effects. Meanwhile, inflation has negative effect on total deposits of Islamic banks which reflects the changes on depositors' consumption pattern during the recession. Interestingly, financial crisis is positively affecting total deposits in Islamic banks. Conclusion: This study provides evidence of general consumer sentiment and deposit behavior. It indicates that in general, due to the 1997/1998 financial crisis experience, bank depositors have trusted Islamic banking to be more resilient in facing financial crisis and hence, inflow of deposits to Islamic banks was happened during 2007/2008 financial crisis.
\end{abstract}

Key words: Islamic banking, financial crisis, financial development, more important, consumer sentiment, islamic banking deposits, macroeconomic variables, conventional counterpart

\section{INTRODUCTION}

Bank is a financial intermediary institution which connecting the surplus group with the deficit group so that productions do not stop and other economic activities can be financed. Mishkin (2007) posits that indirect finance, which involves the activities of financial intermediaries, is many times more important than direct finance, in which businesses raise funds directly from lenders in financial markets, towards economic growth. For the period of 1970-1996, for example, sources of external funds of nonfinancial businesses in Japan were 85\% from bank loans and $15 \%$ from financial markets while in Germany were almost $80 \%$ from bank loans and the rest from financial markets (Mishkin, 2007).

Referring to the importance of financial development for a country, study on causal-relationship between the development of financial intermediaries' activities and economic growth has been carried out extensively. Among the seminal works done in this field is a study by McKinnon (1973); Shaw (1973); King and Levine (1993); Demetriades and Hussein (1996); Levine et al. (2000); Beck et al. (2000); Beck and Levine (2004); Yucel (2009); Adamo et al. (2010); Sadek et al. (2010) and Zreika and Elkanj (2011).

However, to increase its financial intermediaries' activities and thus improve their roles towards economic growth, banks need inflow money. Shareholders' money per se is not sufficient. Banks need inflow money from the people so that be able to give loans or financing to promote productivity and economic growth and at the same time to gain profit for themselves through interest or margin applied. This is why deposits are very important for banks as well as for economy of a country.

Similar to its conventional counterpart, Islamic banks also depend on depositors' money as a major source of funds. In fact, since interest is forbidden in Islam, the flexibility of Islamic bank in collecting inflow money for expenses and financing is limited. For that reason, deposits are even more important in Islamic

Corresponding Author: Muhamad Abduh, Department of Business Administration, Kulliyah of Economics and Management Sciences, International Islamic University, Malaysia 
bank compared to conventional bank. Consequently, significant fluctuation in total deposits is a big concern to Islamic banks and thus need to be carefully managed by being able to identify factors affecting fluctuation of Islamic banking deposits.

Haron and Azmi (2008) and Kasim et al. (2009) demonstrated that Islamic banking deposits fluctuation, is not only affected by changes in profit margin in Islamic banks but also affected by changes in interest rate on conventional deposits and shocks in monetary policy.

Therefore, this study aims to test to what extent the macroeconomics variables, i.e. growth, interest rate and inflation, are able to influence Islamic bank deposits fluctuation. Furthermore, this study is also enriched by incorporating dummy variable of 2007/2008 global financial crisis in order to find out the impact of the event towards Islamic bank deposits fluctuation.

Literature review: In general, the discussion about Islamic bank deposit is divided into three groups. First, is studies which mainly focused on the rate of return of bank deposits and factors influence its volatility. As an example for this kind of study is Chong and Liu (2008) which has attempted to show the relationship between Islamic bank deposit rate with conventional fixed deposit rate in Malaysia. Using time series data ranges between April 1995 April 2004, Chong and Liu (2008) was able to provide evidence that rate of return in Islamic bank deposit is highly pegged to interest rate in conventional bank fixed deposit.

Second, is those studies which are directly discuss the amount of bank deposits and its determinants. One study is done by Haron and Azmi (2008). The study uses macroeconomic variables as explanatory variables to predict the behavior of bank deposits in Malaysia and revealed that growth in the economy and an increase in money supply, composite index and consumer price index, continue to increase Islamic bank deposits. Furthermore, Haron and Azmi (2008) also empirically proven that any increase in rates of interest, the volume of conventional bank deposits will increase and Islamic bank deposits will decrease and vice-versa.

Another study conducted to investigate the behavior of Islamic bank deposits is by Kasim et al. (2009). Using monthly data covering the period from January 1999-2006, this study the impact of monetary policy shock on Islamic bank's balance sheet in Malaysia. The study convincingly provides evidence that the impacts of policy shocks are more destabilizing on the Islamic banks than the conventional banks, in particular, the Islamic bank balance sheet items are more sensitive to interest rate changes compared to their conventional counterparts.

Haron and Ahmad (2000), moreover, examines the effects of conventional interest rates and rate of profits on funds deposited with Islamic banking system in Malaysia. The negative relationship emerged between the interest rate of conventional banks and the total deposits in Islamic banks provides evidence for the existence of the utility maximization theory among the Muslim customers. Meanwhile, Kasri and Kasim (2009) provide similar conclusion for similar study done for Indonesia. It supports Haron and Ahmad (2000); Haron and Azmi (2008) and Kasim et al. (2009) by concluding that higher Islamic deposit is significantly correlated with higher rate of return and lower interest rate.

Third, is a group of studies which combine the discussion between rate of return on bank deposits and the volume of the deposits. Bacha (2004) seminal work discusses causality relationship between conventional bank interest rate with Islamic banking rate of return as well as between conventional fixed-deposit and Islamic bank deposit. Using time series data spread from January 1994-2003, the study shows that the changes in conventional banks interest rates and total deposits Granger cause changes in Islamic banks rate of return and total deposits respectively.

Zainol and Kasim (2010) examines the determinants of rate of return and total deposits in Islamic banking. Utilizing 10 years monthly data spread from January 1997-2008, they found that Islamic banks' rate of return and conventional banks' interest rate are cointegrated and have a long-run equilibrium. Furthermore, the study also indicates the profit motive among Islamic bank's depositors due to the significant impact of the mudharabah deposit rate with the total deposit and negatively significantly related with the changes in conventional fixed-deposit rate.

In the case of inflation, study the relationship between inflation, tax rate increase and consumption behavior in US using data spread from 1971-1984 and conclude that inflation has a substantial impact in consumption. However, this effect is more on services, particularly financial services, rather than on nondurable goods. During the time of high inflation, people reduce their very costly and insignificant expenditures for their real consumption. One of the best choice is by reducing cost of services charged by financial institutions. Huybens and Smith (1999) provides evidence which indicate a significant and economically important, negative relationship between inflation and banking sector development. 
In relation with saving behavior in financial services, Juster and Wachtel (1972) concluded that unanticipated inflation tend to increase households saving in US while fully anticipated inflation is otherwise. However, different result has been shown for the relationship between inflation and households saving behavior in Australia. When studying the roles inflation and consumer sentiment in explaining Australian consumption and savings pattern, Williams and Defris (1981) found that inflation, together with unemployment and general consumer sentiment have significantly affected households consumption and saving pattern. Furthermore, perceived seriousness of inflation is giving more impact on households consumption and saving pattern compared with recorded inflation. Hence, general consumer sentiment plays more significant role in affecting the changes in households consumption and saving pattern in Australia.

Islamic banking said that it can resists towards financial crisis. Is that true? Analyzes the Malaysian data over the period of January 1994 to December 1999 in order to investigate the performance of Islamic banks in pre and post global financial crisis 1997-1998. As anticipated, the conclusion derived is that Islamic banking system is more crises-proof due to its assetlinked nature. However, although he claims that the analysis is for the pre and post crisis, the time period used in his study is not reflecting the post crisis since the impact of the 1997/1998 global financial crisis is felt until beyond the year of 1999 .

Hasan and Dridi (2010) evidences that Islamic banks' credit and asset growth were at least twice higher than that of conventional banks during the crisis, suggesting a growing market share going forward and larger supervisory responsibility. The global crisis gave Islamic banking an opportunity to prove their resilience.

Yudistira (2004) studies the performance of eighteen Islamic banks from South-East Asian and Middle East for the period of 1997-2000. In contrast with other researches, Yudistira (2004) has proven that Islamic banks included in the sample suffered from the global crisis in 1997-1998, however, they performed very well after the difficult periods.

Therefore, hypotheses developed in this study are:

$\mathrm{H} 1$ : Total deposit in Islamic banking is determined by conventional interest rate;

$\mathrm{H} 2$ : Total deposit in Islamic banking is determined by Islamic deposit rate;

H3: Total deposit in Islamic banking is determined by economic growth;

H4 : Total deposit in Islamic banking is determined by inflation;

H5 : Total deposit in Islamic banking is determined by event of financial crisis;

\section{MATERIALS AND METHODS}

Data collection: Data retrieved from Bank Negara official website are Islamic bank Total Deposit (LTD), deposit rate of Islamic (IR) and conventional (CR) bank while Consumer Price Index (CPI), industrial production Index Growth (IG) and based lending rate (BLR) are retrieved from International Financial Statistics. In this study, a new dummy variable namely CRISIS ( $1=$ Crisis, $0=$ otherwise) is proposed and it refers to financial crisis 2007/2008 which was started from subprime mortgage crisis in US.

Proposed model: To study the relationship between the Islamic bank deposits and its determinants, the following model is derived Eq. 1:

$\mathrm{LTD}_{\mathrm{t}}=\beta_{0}+\beta_{1} \mathrm{IR}+\beta_{2} \mathrm{CR}+\beta_{3} \mathrm{CPI}$

$+\beta_{4} \mathrm{IG}+\beta_{5} \mathrm{BLR}+\beta_{6} \mathrm{CRISIS}+\mu_{\mathrm{t}}$

Where:

LTD = Natural Log of Total Deposits of Islamic banks

IR = Average of rate of return in Islamic banking investment deposits

$\mathrm{CR}=$ Average of rate of return in conventional banking fixed-deposits

CPI = Consumer Price Index as a proxy for inflation (reference base $2005=100$ )

IG = Growth of industrial production index (reference base $2005=100$ )

BLR = Based Lending Rate as a proxy for rental rate CRISIS = Dummy variable of crisis which was recorded to happen on the fourth month of 2007 (M4-2007) until month twelve of 2008 (M12-2008). Dummy is "1" for crisis and " 0 " otherwise

Cointegration test: Cointegration means that even though the variables are not stationary individually, the linear combination between two or more variables may be stationary. To test the cointegration, Johansen cointegration test is used in this study.

When two or more variables are cointegrated, they will show the existence of long-term relationship if the variables contain mutual stochastic trend. If this is the case, there exists at least one Granger's causality either in one or bi-directional (feedback effect).

Vector error correction model: Cointegration techniques of Granger (1986); Engle and Granger (1987) and Johansen and Juselius (1990) have given a significant contribution to Granger's Causality test. If 
Am. J. Applied Sci., 8 (12): 1378-1383, 2011

cointegration is found from the variable series, Error Correction Term (ECT) obtained from cointegration regression must be taken into consideration in the causality test to avoid the problem of missspecification (Granger, 1986).

VECM is a restricted VAR designed and used for non-stationary variables known to be cointegrated. VECM specification restricts the long-run behavior of endogenous variables to converge to their cointegrating relationship whilst allowing for short-run adjustment dynamics. Through the ECT, VECM allows the discovery of Granger's causality relation. In addition, VECM method allows the differentiation of short-term and long-term relationships. Error term with lagged parameter, ECT (-1), is an adaptive parameter measuring the short-term dispersal from long-term equilibrium. In short-run, the variables may disperse from one another which will cause system inequilibrium. Hence, the statistical significance of the coefficient associated with ECT (-1) provides us with evidence for an error correction mechanism that drives the variables back to their long-term relationship.

\section{RESULTS}

Unit root test: The results of the Augmented Dickey Fuller (ADF) and Phillip-Perron (PP) tests for the unit root test are provided Table 1 . The value of ADF and PP t-statistic will be compared to the critical value given by Engle and Granger (1992). From the results, it is found that the null hypothesis of non-stationarity at level for the time series of LTD, IR, CR, CPI, IG and BLR cannot be rejected. Nevertheless, all null hypotheses are rejected for every test at first difference. The results indicate clearly that all variables are stationary at first difference or I (1).

Cointegration test: After knowing that all variables are non-stationary and they have the same order of integration, we then proceed to test whether the linear combination of the series is stationary. The test to be employed is the cointegration test of Johansen and Juselius (1990).

The Schwarz and Hannan-Quinn information criterion for lag order selection criteria had indicated that, at lag interval equal to 1 , at least one cointegration exists at $1 \%$ level of significance Table 2 .

Vector error correction model: Normalizing LTD, following in Eq. 2 is the vector error correction term or long term relationship among the variables, with the number in parentheses are t-ratios:

$$
\begin{gathered}
\text { Ect }=\text { LTD-0.328 Crisis+0.004 CPI+0.71 BLR } \\
\begin{array}{c}
(-4.287) \quad(0.289) \\
+25.6 \text { IG-1.36 IR +1.07CR-15.26 }
\end{array} \\
(15.123)(-3.413)(4.287)
\end{gathered}
$$

Table 1: Unit root test

\begin{tabular}{lllll}
\hline & ADF & & PP & \\
Variables & Level & 1st difference & Level & 1st difference \\
\hline LTD & -1.178 & $-10.08^{* * *}$ & -1.178 & $-10.06 * * *$ \\
IR & -2.105 & $-12.80^{* * *}$ & -2.235 & $-12.73 * * *$ \\
CR & -2.337 & $-7.933^{* * *}$ & -2.311 & $-7.993 * * *$ \\
CPI & -2.740 & $-7.879 * * *$ & -2.419 & $-7.879 * * *$ \\
IG & -2.937 & $-6.963 * * *$ & -2.493 & $-6.912 * * *$ \\
BLR & -1.869 & $-5.488^{* * *}$ & -1.802 & $-8.896 * * *$ \\
\hline
\end{tabular}

***: Significant at $1 \%$ level of significance

Table 2: Cointegration results (Lag interval $=1$ )

\begin{tabular}{llll}
\hline Lag intervals & Null hypothesis & Trace & Max \\
\hline 1 & $\mathrm{r}=0$ & $234.91 \mathrm{a}(125.62)$ & $134.43 \mathrm{a}(46.231)$ \\
& $\mathrm{r}=1$ & $95.486(95.753)$ & $39.059(40.077)$ \\
& $\mathrm{r}=2$ & $56.427(69.818)$ & $26.878(33.877)$ \\
\hline${ }^{\text {a): }}$ Rejection of the hypothesis at alpha level is 1\%. () is 0.05 critical value
\end{tabular}

Table 3: Vector error correction model

\begin{tabular}{llr}
\hline & Dependent variable: $\Delta$ LTD & \\
Explanatory variables & coefficient & t-statistic \\
\hline ECT $(-1)$ & -0.004693 & $-2.176^{* *}$ \\
CRISIS & 0.014229 & $2.531^{* *}$ \\
$\Delta$ CPI (-3) & -0.012984 & $-3.071^{* * *}$ \\
$\Delta$ LTD (-6) & 0.203239 & $2.3441^{* *}$ \\
$\Delta$ CR $(-1)$ & 0.043864 & 1.645663 \\
$\Delta$ IR $(-1)$ & -0.015436 & -0.793428 \\
$\Delta$ IG $(-12)$ & -0.040743 & -1.260841 \\
$\Delta$ BLR $(-12)$ & 0.042398 & 1.483778 \\
Constant & 0.013511 & $5.124 * *$ \\
& $\mathrm{R}^{2}=0.22$ & \\
& F-Statistic $=3.86(0.000)$ & \\
Diagnostics & Jarque-bera $=1.604(0.45)$ & \\
& LM $=0.43(0.65)$ & \\
& RESET $=0.81(0.37)$ & \\
\hline
\end{tabular}

Notes: (i) $* * *$ : Indicates significance at less than 1\%, $* *$ : Indicates significance at less than 5\%; (ii) LM refers to the Lagrange Multiplier statistic for serial correlation, RESET refers to Ramsey's RESET test of misspecification of the functional form and $\mathrm{ARCH}$ represents the test for Autoregressive Conditional Heteroscedasticity; (iii) The probability value of each diagnostic test is given in parentheses. (iv) The ECT (-1) term emanates from the cointegrating equation of the unique vector

The vector error correction model is presented in Table 3 and its discussion is brought to the next section.

\section{DISCUSSION}

The relationship sign for all variables in the long run are as expected Eq. 2. The negative sign for dummy variable CRISIS implies that Islamic banks have received a positive image and good trust from their depositors regarding their resilient towards banking crisis. Therefore, whenever crisis comes, it seems that their depositors will not withdraw substantially in the long run, but more depositors come in and deposit their money instead. This supports hypothesis 5 (H5) proposed in this study. 
Meanwhile, rational actions from depositors also reflected from the relationship sign from the remaining variables. For CPI and BLR, the higher the inflation and rental price, the more people need cash money for expenses and thus leads to withdrawal action or reduces total deposit in general. Similarly, for IG, the higher the production level, the more depositors move their money from their banks for more investments.

The impact of the rate of return in both Islamic (IR) and Conventional (CR) deposit upon the deposit/withdrawal behavior of Islamic bank depositors also as being expected. For IR, increment in rate of return will increase the deposit level in Islamic banking, while for $\mathrm{CR}$, increment in interest rate of fixed deposit will decrease the deposit level in Islamic banking. These confirm findings from previous studies like Haron and Ahmad (2000); Bacha (2004); Kasim et al. (2009); Kasri and Kasim (2009) and Zainol and Kasim (2010).

It is interesting to see that crisis is positively and significantly affecting the Islamic bank deposits in both the long run and the short run. This might provide new evidence of differences between Islamic and conventional banking depositors' behavior.

During the 1997-1998 global financial crisis, in all countries affected by it, most of the conventional banks, if not all, are affected and suffered by it. Thanks to deposit insurance, they finally managed to pay back majority of their liability to the depositors. Islamic banks are less affected by the crisis due to its linkedassets to real economy (Hasan and Dridi, 2010). Furthermore, in some country like Indonesia, as reported in Bank Muamalat Indonesia annual report, as the only representative of Islamic bank in Indonesia from 1993-1999, was not affected by crisis and even able to increase its capital adequacy ratio (CAR) up to $12 \%$ in the year 1998 .

People do record the 1997-1998 financial crisis event and remember very well about the resilient of Islamic bank towards it. Therefore, when the subprimemortgage crisis was predicted to spread to other countries and will create worst global financial crisis, people react by running away from their banks and move their deposits to Islamic banks which was assumed to have a better stability compared with the conventional banks. Hence, Islamic bank deposits increases due to people expectations upon its less impact against financial crisis. This might explain the positive and significant relationship between the crisis and Islamic bank deposits in the short run and long run.

Meanwhile, the negative and significant coefficient of inflation in the short run VECM model can be explained as following. The direction of relationship between inflation and Islamic bank deposits in the present study is not in contrary with the general theory of inflation and saving and consumption behavior nexus. Although the banks increase the rate of return, as the inflation increases, people need more money for they consumptions and expenditures, hence affecting their total saving and deposits negatively (Juster and Wachtel, 1972; Williams and Defris, 1981).

Despite fruitfully result for the variable of crisis and inflation, the present study cannot provide strong evidence of the short run impact of shock in other variables i.e., conventional bank interest rate, economic growth, rental rate and the Islamic banking rate of return.

To test the robustness of the error correction model, we apply a number of diagnostic tests. No evidence found of normality failure, serial correlation, misspecification of the functional form, heteroskedasticity and Autoregressive Conditional Heteroskedasticity (ARCH) effect in the disturbances.

\section{CONCLUSION}

This study aims to examine the impact of macroeconomic variables on Islamic bank deposits fluctuation. In addition, bank-specific variables like Islamic and conventional bank rate of return and dummy variable of crisis are also included in the analysis to enrich the discussion in this chapter. The method of analysis utilized are cointegration and Vector Error Correction Model (VECM).

Both in the short and long run, all independent variables have reasonable direction in relationship with Islamic bank's total deposit to explain the rational behavior of Islamic bank depositors. The ability to uncover the impact of crisis towards the Islamic bank deposit movement is one of the significant contribution in this study. It is proven statistically that crisis event gives positive effect and inflation gives negative effect upon Islamic bank deposits level in the short run and long run. Hence, it could be true that general sentiment of consumers plays more role in their banking behavior.

Future research is still required in this broad area of Islamic banking. Some recommendations offered are to; (i) implement the same methods and objectives of this study for different countries and (ii) utilize more sophisticated statistical methods in order to obtain more comprehensive views.

\section{REFERENCES}

Adamo, R., A. Coscarelli, D. Federico and A. Notte, 2010. The ethical and non ethical mutual funds comparison. Am. J. Econ. Bus. Admin., 2: 360365. DOI: 10.3844/ajebasp.2010.360.365 
Bacha, O.I., 2004. Dual banking systems and interest rate risk for Islamic banks. J. Account. Commerce Finance Islamic Perspective, 1: 1-42.

Beck, T. and R. Levine, 2004. Stock markets, banks and growth: panel evidence. J. Bank. Finance, 28: 423-442. DOI: 10.1016/S0378-4266(02)00408-9

Beck, T., R. Levine and N. Loayza, 2000. Finance and the sources of growth. J. Financial Econ., 58: 261300. DOI: 10.1016/S0304-405X(00)00072-6

Chong, B.S. and M.H. Liu, 2008. Islamic banking: Interest-free or interest-based? Pacific-Basin Finance J., 17: 125-144. DOI: 10.1016/j.pacfin.2007.12.003

Demetriades, P.O and K.A. Hussein, 1996. Does financial development cause economic growth? Time-series evidence from 16 countries. J. Dev. Econ., 51: 387-411. DOI: 10.1016/S03043878(96)00421-X

Engle, R.F. and C.W.J. Granger, 1987. Cointegration and error correction: Representation estimation testing. Econometrica, 55: 251-276. DOI: $10.2307 / 1913236$

Engle, R.F. and C.W.J. Granger, 1992. Long-Run Economic Relationships. 1st Edn., Oxford University Press, USA., ISBN-10: 0198283393, pp: 312.

Granger, C.W.J., 1986. Developments in the study of cointegrated economic variables. Oxford Bull. Econ. Stat., 48: 213-228. DOI: 10.1111/j.14680084.1986.mp48003002.x

Haron, S. and N. Ahmad, 2000. The effects of conventional interest rates and rate of profit on funds deposited with Islamic banking system in Malaysia. Intl. J. Islamic Financial Services, 1: 1-7.

Haron, S. and W.N.W. Azmi, 2008. Determinants of Islamic and conventional deposits in the Malaysian banking system. Managerial Finance, 34: 618-643. DOI: $10.1108 / 03074350810890976$

Hasan, M. and J. Dridi, 2010. The effects of the global crisis on Islamic and conventional banks: A comparative study. J. Int. Commerce, Econ. Policy, 2: 163-200. DOI: 10.1142/S1793993311000270

Huybens, E. and B.D. Smith, 1999. Inflation, financial markets and long-run real activity. J. Monetary Econ., 43: 283-315. DOI: 10.1016/S03043932(98)00060-9

Johansen, S. and K. Juselius, 1990. Maximum likelihood estimation and inference on cointegration with applications to the demand for money. Oxford Bull. Econ. Stat., 52: 169-210. DOI: 10.1111/j.1468-0084.1990.mp52002003.x

Juster, F.T. and P. Wachtel, 1972. Inflation and the consumer. Brook. Papers Econ. Activity, 1972: 71121. DOI: $10.2307 / 2534115$
Kasim, S.H., M.S.A. Majid and R.M. Yusof, 2009. Impact of monetary policy shocks on the conventional and Islamic banks in a dual banking system: Evidence from Malaysia. J. Econ. Coop. Dev., 30: 41-58.

Kasri, R. and S. Kassim, 2009. Empirical determinants of saving in the Islamic banks: Evidence from Indonesia. J. King Abdulaziz Univ.: Islamic Econ., 22: 181-201.

King, R.G. and R. Levine, 1993. Finance and growth: Schumpeter might be right. Q. J. Econ., 108: 717737. DOI: $10.2307 / 2118406$

Levine, R., N. Loayza and T. Beck, 2000. Financial intermediation and growth: Causality and causes. J. Monetary Econ., 46: 31-77. DOI: 10.1016/S03043932(00)00017-9

McKinnon, R.I., 1973. Money and Capital in Economic Development. 1st Edn., Brooking Institution Press, Washington, DC., ISBN: 9780815756132, pp: 184.

Mishkin, F., 2007. The Economics of Money, Banking and Financial Markets. 8th Edn., Pearson Addison Wesley, Boston, Sydney, ISBN: 9780321449146, pp: 660 .

Shaw, E.S., 1973. Financial Deepening in Economic Development. 1st Edn., Oxford University Press, New York, pp: 260.

Sadek, D.M., N.S. Zainal, M.S.I.M. Taher, A.F. Yahya and M.R. Shaharudin et al., 2010. Service quality perceptions between cooperative and Islamic Banks of Britain. Am. J. Econ. Bus. Admin., 2: 1-5. DOI: 10.3844/ajebasp.2010.1.5

Williams, R.A. and L.A. Defris, 1981. The roles of inflation and consumer sentiment in explaining Australian consumption and savings patterns. J. Econ. Psychol., 1: 105-120. DOI: 10.1016/01674870(81)90033-7

Yucel, F., 2009. Causal relationships between financial development, trade openness and economic growth: The case of Turkey. J. Soc. Sci., 5: 33-42. DOI: $10.3844 /$ jssp.2009.33.42

Yudistira, D., 2004. Efficiency in Islamic banking: An empirical analysis of eighteen banks. Islamic Econ. Stud., 12: 1-19.

Zainol, Z. and S.H. Kassim, 2010. An analysis of Islamic banks' exposure to rate of return risk. J. Econ. Coop. Dev., 31: 59-84.

Zreika, M. and N. Elkanj, 2011. Banking efficiency in lebanon: An empirical investigation. J. Soc. Sci., 7: 199-208. DOI: 10.3844/jssp.2011.199.208 